\title{
A PRODUÇÃo dA VIOLÊNCIA \\ E DISPOSITIVOS DE INTERVENÇÃO ${ }^{1}$
}

\author{
Juliane A. Chaves, Kenia C. Kale, Miralda Santos, \\ Verônica G. Kubaski ${ }^{H}$ \\ Silvia Helena Tedesco ${ }^{\mathrm{HH}}$
}

Palavras-chave: Violência. Dispersão semiótica. Adesão ao tratamento.

INTRODUÇÃO: Este projeto faz parte do estágio/pesquisa do curso de Psicologia da Universidade Federal Fluminense instalado numa instituição pública de atendimento clínico-integrado na prevenção e tratamento da violência e abuso de drogas. Em etapa anterior da pesquisa, constatamos a existência de diferentes linguagens habitando a instituição: a dos técnicos e a da clientela atendida. O distanciamento entre esses territórios semióticos/subjetivos foi pensado como fonte de obstáculos ao funcionamento geral da instituição. Na etapa atual da pesquisa, visamos ampliar o levantamento de tais dicotomias territoriais, através pesquisa de outras modalidades de binarização.

OBJETIVOS: Elegeu-se como objetivo geral o levantamento de dicotomias existenciais em jogo na instituição.

METODOLOGIA: A proposta fundamenta-se no modelo de pesquisa-intervenção, ou seja, o levantamento das informações exigem a inserção dos pesquisadores no funcionamento cotidiano da instituição. Como primeiro passo para o reconhecimento das divergências semióticas, elegemos a análise de dois temas recorrentes nos discursos vigentes: violência e drogas. Através de observação participante e de entrevistas coletivas com dois grupos de participantes da instituição: adolescentes e seus responsáveis; iniciou-se o levantamento e categorização dos diferentes sentidos atribuídos ao elo entre violência e uso/abuso de drogas.

RESULTADOS: Constatamos que dois grupos revelam-se muito distanciados no sentido atribuído a esta relação. Segundo os adolescentes é apenas o uso abusivo e inadequado drogas, ou seja, no momento em que não se pode mais controlar o uso das drogas que elas podem estar associadas à violência: "Morte, briga, vários bagulhos louco". Ao mesmo tempo repartem o território da favela entre os amigos, entre eles, “ a família comando vermelho”, que nomeiam como o "lado certo da vida errada”; a família natural - e os outros (inimigos) - os policiais, cuja conduta sempre arbitrária é traduzida como violência "sobem largando o dedo, sem saber se é trabalhador, criança”; os vacilões (quem dá volta no tráfico); os caras da pista que esculacham com a cara dos moradores; e ainda "os alemães”,

\footnotetext{
${ }^{1}$ Trabalho apresentado na X Semana de Extensão da UFF, no Campus Gragoatá da UFF, em 09/11/2005.

${ }^{H}$ Graduandas do Curso de Psicologia da UFF.

${ }^{H H}$ Professora Adjunta do Departamento de Psicologia da UFF, coordenadora do projeto.

E-mail: stedesco@novanet.com.br
} 
ou seja, o Terceiro e o Ada. O discurso dos responsáveis pelos adolescentes também mostrou-se excessivamente dicotomizado. Discriminaram "o mundo do bem” - "mundo da luz", da televisão, do exército, possíveis policiais e políticos honestos que tentam acabar ou reduzir o tráfico - do "mundo da escuridão", das ruas, das drogas que os filhos usam, da boca de fumo, dos policiais e políticos que nada querem mudar. Além disso, chama atenção o fato de que os pais falam acerca das drogas e do tráfico apoiados bem em informações que circulam na mídia do que através de suas próprias experiências, sejam elas diretas ou mediadas pelos filhos.

CONCLUSÃO: Constatam-se realidades distanciadas, desencontradas em seus valores e crenças. Reconhecemos aí nestes territórios discrepantes, com fronteiras hermeticamente fechadas, o exercício de binarização, da repartição do mundo em blocos rígidos, cujas fronteiras intransponívies não deixa espaço para a experiência da auteridade. Esta, uma vez inventada como inimigo a ser combatido, confere sentido de beligerância a todo e qualquer contato entre modos de existência distintos, esclarecendo assim os atos de exclusão recíproca que aí dominam, produtores de relações de atos recíprocos de dominação e de violência.

Apoio: CNPq e FAPERJ. 